\title{
The Effect of Fiscal Incentives on Business R\&D
}

\author{
Valeria Bucci \\ Department of Economics, University of Salento, Lecce, Italy and Sose SpA, Rome, Italy
}

\section{Email address:}

valeriabucci@gmail.com

\section{To cite this article:}

Valeria Bucci. The Effect of Fiscal Incentives on Business R\&D. International Journal of Economics, Finance and Management Sciences. Vol. 7, No. 2, 2019, pp. 37-44. doi: 10.11648/j.ijefm.20190702.11

Received: February 19, 2019; Accepted: March 30, 2019; Published: April 18, 2019

\begin{abstract}
This paper analyses the determinants of business R\&D choices. In particular, it provides new empirical evidence on the effectiveness of fiscal policies aimed at driving companies to invest in R\&D activity. By computing two very accurate proxies for firm-specific tax savings achievable when investing in R\&D, and by exploiting exogenous changes in fiscal legislation in Italy, this study investigates if fiscal considerations affect companies' choice to invest in R\&D and how much to spend in such activity. The empirical analysis is based on an unbalanced panel data set composed of 163 Italian companies, covering the years 2004-2010. A two-step approach has been implemented, by combining a probit and a tobit estimation model. The results deliver strong empirical evidence that fiscal incentives significantly affect business R\&D choices, by one side, increasing companies' likelihood to invest in R\&D, and, by the other, fostering companies' R\&D expenditure.
\end{abstract}

Keywords: Innovation, R\&D, Fiscal Incentives, Marginal Tax Savings

\section{Introduction}

This paper analyses the determinants of business R\&D choices, studying, in particular, the effectiveness of fiscal incentives in driving companies to invest in R\&D activity.

During the last decades, an increasing number of Governments worldwide adopted policies aimed at fostering and stimulating private $R \& D$ expenditure. The main motivation for the implementation of such policies is the consideration that R\&D is a key driver for growth, innovation and competitiveness of national economies, as strongly supported by economic theory and empirical evidence [1-2]. However, according to economic theory, companies underinvest in R\&D activity and markets usually fail to provide the socially optimal level of R\&D. Indeed, the output of R\&D has some characteristics of public-good and companies investing in $R \& D$ cannot entirely internalize its benefits. Therefore, public intervention is necessary to drive companies to invest in $R \& D$ activity, to boost private $R \& D$ expenditure and, consequently, to raise the social welfare [3].

In order to increase business $R \& D$ expenditure, governments can design policy interventions in two main ways. They can offer public R\&D resources directly, through grants or procurement, or they can provide support indirectly, through fiscal incentives, such as R\&D tax credits [4-5]. The main difference is that direct policies support specific projects, having high social potential returns, while fiscal incentives allow private companies to select which projects to fund.

Countries differ significantly in their use of R\&D policies. The optimal balance of these tools varies significantly from country to country, since each policy addresses different market failures and stimulates different types of investments. In most OECD countries direct government interventions have been the prevailing instrument used to foster private $\mathrm{R} \& \mathrm{D}$; however, in the last two decades, a growing shift towards fiscal incentives (in particular tax credits) has been observed in several countries [6].

At present, R\&D fiscal incentives are admitted by more than 20 OECD countries (from 12 and 18 in 1995 and in 2004, respectively). Moreover, not only advanced, but also developing countries (such as Brazil, China, India, South Africa) provide generous fiscal incentives to support business R\&D [7-8].

Wide empirical literature evaluates the effectiveness of $R \& D$ policies in increasing R\&D expenditure. While much of the early literature focused mainly on evidence from US companies, over the last few years a growing number of micro-econometric studies analyzing other parts of the word emerged, such as developing countries [9-11].

A wide share of $R \& D$ literature focuses on innovation 
inputs of companies (i.e. R\&D expenditure, the value of tangible assets or employment level), finding convincing evidence that such inputs can be affected by fiscal incentivizing policies. ${ }^{1}$

The most compelling evidence on the positive effect of fiscal incentives on $R \& D$ choices has been provided by studies that compute a user cost of $\mathrm{R} \& \mathrm{D}$ and estimate the response of $R \& D$ to this price variable, by using a quasiexperimental approach [14]. The main limit of this approach is that the price variable does not contain a direct measure of fiscal incentives, and does not take into account that a wide range of companies' characteristics (such as operating loss position or R\&D investment level) could affect the possibility of benefiting from R\&D policies [12].

This paper tries to overcome this hurdle of previous literature by computing an accurate measure for the firmspecific tax benefit stemming from R\&D investment. The identification strategy relies on the presence in the Italian fiscal system of a double fiscal advantage for companies investing in R\&D activity: (i) the deductibility of R\&D expenditure from corporate income tax; (ii) the tax credit system for R\&D expenditure. Therefore, two direct measures of fiscal advantage of R\&D investments have been computed. The first is the corporate marginal tax rate (MTR), which measures the fiscal benefit due to R\&D deductibility. The second is the marginal tax credit rate (MTCR), which measures the tax credit achievable by companies investing in R\&D activity.

The empirical analysis is based on a panel of Italian companies covering the period 2004-2010. The identification strategy exploits the exogenous variation of the statutory tax rate and tax base brought about by several fiscal reforms implemented in the period. In particular, it takes advantage of the introduction in 2006 of the total tax credit system for R\&D expenditure.

Few studies in R\&D literature are focused on the analysis of the Italian context. The main reason for this lack in literature is the low diffusion of micro data on Italian companies' R\&D expenditure. The Survey on Manufacturing Firms by Microcredito-Capitalia and the Italian Community Innovation Survey (CIS) by ISTAT represent the two main sources of R\&D microdata. ${ }^{2}$ However, the main limit of such surveys is that such data are available up to the early 2000 s. Bronzini and Piselli (2016) overcome the unavailability of updated R\&D data by focusing on patent applications and investigating how fiscal incentives could affect the output of R\&D activity [17]. However, the use of patent application has some limitation: fiscal incentives could have an impact on $R \& D$ expenditure but no effect on the number of patent applications. Usually the achievement of a patent requires a long period and it is possible that a patent does not originate from $R \& D$ activity.

\footnotetext{
${ }^{1}$ Hall and Van Reenen (2000) and Mairesse and Mohen (2010) provide accurate reviews of methods and results obtained in this field [12-13].

${ }^{2}$ Using such surveys, Hall, Lotti and Mairesse (2009), and Cerulli and Potì (2012) find that companies receiving a subsidy significantly increase R\&D activity [15$16]$.
}

This paper overcomes the patents' data limitation and the unavailability of recent survey micro-data by using the balance sheet data of Italian companies provided by ORBIS (a Bureau van Dick database), containing detailed information on companies' R\&D expenditure.

Finally, this study provides some significant policy implications, showing if and how much R\&D policy adopted in Italy has been effective in fostering and increasing business R\&D expenditure.

The remainder of this paper is organized as follows. Section 2 provides background information on the fiscal treatment of R\&D investments in the Italian context. Section 3 develops the main hypotheses tested in this study and describes the research design. Section 4 illustrates sample composition, describes the data and presents summary statistics of the key variables. Section 5 discusses the estimation results and provides some robustness check analysis. The final section provides some concluding remarks.

\section{R\&D Fiscal Incentives: $M T R$ and MTCR}

The allowance of fiscal incentives represents the main public policy instrument adopted by Governments worldwide in order to enhance and to increase business $\mathrm{R} \& \mathrm{D}$ expenditure.

The Italian fiscal system imposes two different taxes on companies: IRES and IRPEG.

The first is the corporate income tax, IRES (Imposta sul Reddito delle Società). The IRES tax base is constituted by accounting income (as defined by the Italian Civil Code), subject to some adjustments. From 2004 to 2007 the IRES tax remained stable at $33 \%$; it has been reduced to $27.5 \%$ from 2008 onwards. The corporate tax regime allows companies with negative taxable income to carry-forward losses, to offset the taxable income, up to the following 5 years.

In addition to IRES, Italian companies carrying out productive activities are subject to the payment of the regional production tax, IRAP (Imposta sul Reddito delle Attività Produttive). Up to 2007, the statutory rate of IRAP has been $4.25 \%$, while it has been reduced to $3.9 \%$ by the 2008 financial law. However, considered that IRAP is a tax levying on a regional basis, regions are allowed to increase or decrease the standard rate up to $0.92 \%{ }^{3}$

The main fiscal incentive allowed to Italian companies investing in $R \& D$ is the possibility to deduct fully $R \& D$ expenses from IRES tax base. The deduction has the effect of reducing the marginal cost of $R \& D$ investments faced by firms [12].

In addition to deductibility, in 2006, in order to foster and increase business $\mathrm{R} \& \mathrm{D}$ investments, the Italian fiscal

\footnotetext{
${ }^{3}$ Different IRAP tax rates are applied to companies belonging to specific economic sectors: for example, a tax rate higher than the statutory one is applied to banks and financial entities or to insurance corporations; on the contrary a reduced tax rate is applied to the agricultural sector.
} 
authority adopted a total tax credit system for R\&D expenditure. ${ }^{4}$ Starting from 2007, any company involved in R\&D was allowed to obtain a tax credit equal to $10 \%$ of $\mathrm{R} \& \mathrm{D}$ expenditure. The tax credit could not exceed the value of 15 million euro ${ }^{5}$ in each fiscal year. The tax credit could be used to pay both IRES and IRAP.

Therefore, due to $R \& D$ deductibility a marginal increase in R\&D expenditure implies a reduction in tax liabilities measured by MTR, which is defined as the present value of current and expected future taxes paid on an additional unit of income earned today.

If a firm has positive taxable income, the $M T R$ is equal to the statutory IRES tax rate. Otherwise, if a firm has no taxable income in year $t$, an additional unit of income earned reduces the losses that can be carried forward and used to offset the taxable income, during the following 5 years. In this case, the MTR is equal to the discounted value of the taxes paid on the marginal unit of income in the first year when the firm is expected to have positive taxable income.

In order to compute the true value of MTR, two sets of information are required. The first regards the corporate taxation rules, namely the level of the statutory tax rate. The second is the expectation of future income flows. Following [18], the value of expected taxable income has been proxied by using the Graham-Shevlin methodology [19-22]. Then, these values have been used to compute the marginal tax rate for each company in the sample. ${ }^{6}$

Due to the tax credit, a marginal increase in $R \& D$ expenditure implies a reduction in tax liabilities measured by $M T C R$, which is equal to the marginal increase in the tax credit, due to a marginal increase in $\mathrm{R} \& \mathrm{D}$ expenditure.

The computation of $M T C R$ requires knowledge of the statutory tax rate, R\&D expenditure, taxable income and current taxes (IRES and IRAP).

In year $t$, an additional unit of company's R\&D expenditure implies a marginal increase in tax credit (and hence a marginal reduction in a company's tax burden) equal to IRES/IRAP statutory tax rate, if three conditions are met:

(i) the value of current tax is positive;

(ii) the value of current tax is higher than $10 \%$ of $\mathrm{R} \& \mathrm{D}$ expenditure;

(iii) $10 \%$ of $\mathrm{R} \& \mathrm{D}$ expenditure is lower than the threshold (euro 15 million in 2007, and 50 from 2008 onwards).

In any different scenario, a marginal increase in $R \& D$ expenditure would not affect the tax burden, so MTCR would be equal to zero.

\section{Research Design}

The main purpose of this paper is to investigate the

4 R\&D fiscal incentives appeared for the first time in Italian fiscal system during the nineties, when tax credits were allowed to small and medium firms employing new R\&D workers.

5 Financial law no. 244/2007 (article 1, section 66) increased this limit to 50 million euro.

6 In order to compute the MTRs a microsimulation model has been developed. Further details on such methodology are available upon request. effectiveness of R\&D policies adopted in Italy to drive companies to invest in R\&D activity. The empirical analysis investigates the existence of a fiscal effect affecting both the decision of companies to invest in $\mathrm{R} \& \mathrm{D}$ and how much to spend in such activity.

The identification strategy relies on the tax-burden reductions achievable by companies investing in $R \& D$. Due to the possibility to deduct R\&D expenses from IRES taxable income, and to receive $R \& D$ tax credits, companies facing a higher marginal tax rate and/or a higher marginal tax credit rate, could be more likely to invest in $R \& D$. Therefore, the empirical analysis tests whether an increase in $M T R$ and/or $M T C R$ entails an increase in both the probability that companies will invest in $R \& D$ and in private $R \& D$ expenditure. Hence, the hypotheses to be tested are stated formally as:

H1: The probability to invest in $R \& D$ increases with an increase in MTR and/or MTCR.

$\mathrm{H} 2$ : R\&D expenditure increases with an increase in MTR and/or MTCR.

The empirical analysis adopts a two-step approach. The first step is focused on companies' decision to invest in R\&D. A binary choice model has been estimated, using as dependent variable a dummy showing companies investing in R\&D activity. The multivariate analysis relies on a probit random effects model. ${ }^{7}$

The second step investigates the effects of fiscal benefits on $R \& D$ intensity, measured by the ratio between $R \& D$ expenditure and total assets [23]. The dependent variable is a doubly truncated random variable, which varies between 0 and 1. A common approach to dealing with the problem of censored variables is the tobit model [24-25].

The baseline specification is the following:

$$
R \& D_{i t}=\alpha+\beta M T R_{i t}+\gamma M T C R_{i t}+\varphi X_{i t}+\varepsilon_{i t}
$$

where $R \& D_{i t}$ is the dummy variable showing companies investing in R\&D in the first step of the empirical analysis, while it is equal to the value of $\mathrm{R} \& \mathrm{D}$ expenditure expressed as a proportion of total assets in the second step. The parameters of interest are $\beta$ and $\gamma$, which capture the fiscal effect on companies' R\&D decisions.

The vector $X_{i t}$ contains several factors identified by previous empirical literature as able to drive $R \& D$ companies' behaviour. Prior research has found that companies' size is an important determinant of R\&D expenditure and innovation activity. Larger companies could benefit from economies of scale and scope, have a better organizational structure and are less exposed to capital market imperfections [26-27]. In line with previous literature, a positive link between company's size and R\&D choice is expected: the larger the company is, the higher would be both its probability to invest in $R \& D$ and $R \& D$ expenditure. Two variables have been used to proxy for this "size effect". The

\footnotetext{
7 The choice of the random effects model is driven by the structure of the sample. Since the empirical analysis is based on a not exhaustive sample extracted by a population, the random effects model allows to make inference about the population from which these cross-section data came from.
} 
first, $S$, is the log of sales [28]. The second, LARGE, is a dummy variable based on companies' added value. Following [29], the variable $L A R G E$ is set equal to one if the added value of a company is above its median value, otherwise it results equal to zero. Moreover, the number of employees could provide a measure of companies' size [23]. ${ }^{8}$ Due to unavailability of such information for several companies in several years, the inclusion of this control significantly decreases the number of observations. Therefore, this additional variable is used to test the robustness of the main empirical results.

Companies' age could be a significant factor linked to $R \& D$ choices. Several studies have claimed that older firms are more reluctant to pursue innovation, while younger firms have a higher propensity towards R\&D [30-31]. The empirical analysis controls for the age of companies, using the log of the number of years since its foundation, expecting to find a negative correlation between companies' age and R\&D.

$R \& D$ choices could be affected by market competition. This relationship is widely discussed in the literature. The standard theoretical model predicts that innovation activity should decline with competition, since a higher competition lowers monopolistic profits of successful innovators [32]. However, several empirical works find a positive correlation between market competition and innovation [33]. To control for the impact of competition, following [23, 31], among the controls it is included the market share variable, relating company's sales to those of its economic sector.

The geographical location could be an important element to take into account, as provincial $\mathrm{R} \& \mathrm{D}$ incentives could differ [34-35]. To control for this aspect, three regional dummies have been included in the regression model: NorthEast, North-West and Centre-Southern regions. ${ }^{9}$

R\&D distribution of firms varies significantly by sectors. More innovative companies are typically concentrated in technologically advanced industries, whereas companies in more traditional sectors are less likely to invest in R\&D [23, 35]. To control for these differences, industry dummies, measured on the NACE two-digit level, have been included in the empirical model.

R\&D choices could be affected positively by past innovative practices, proxied by the number of patents achieved by companies or by the presence of $R \& D$ departments [36-37]. Moreover, companies' trade openness could affect R\&D [34]. Companies active in exportation usually face higher international competition and are this could affect their likelihood to strengthen their competitiveness through R\&D. These are arguably the most important omitted variables not included in the empirical analysis, due to data unavailability.

8 Almus and Czarnitzki (2003) underline that using the number of employees as control variable endogeneity may arise: companies benefitting from fiscal incentives may hire R\&D staff, and thus their employment increases [23]. However, R\&D staff represents a small proportion of all employees of Italian companies. Hence, R\&D fiscal incentives could affect the number of R\&D staff, but this change is not significant compared to the total number of employees.

9 The choice to use three macro-regions is due to the peculiarity of sample composition, characterized by only few companies based in the Centre and Southern regions.

\section{Sample Composition and Description}

The empirical analysis is based on a panel data set composed of Italian companies observed over the years 2004-10. Several reforms of Italian corporate income tax, together with the introduction of a tax credit for $R \& D$ expenditure in 2007 , make this period particularly interesting and provide an ideal setting for testing the effect of fiscal variables on companies' $R \& D$ choices.

The data are gathered from the ORBIS database, containing accounting information on Italian corporations. Initially, it has been identified a balanced panel composed by 163 companies having a known value of $R \& D$ expenditure (for which the value of R\&D expenditure is not a missing data) and balance sheet data in every year between 1999 and $2010 .{ }^{10}$ The result of the exclusion of inconsistent data ${ }^{11}$ is an unbalanced panel data set.

Table 1 provides summary statistics on the fiscal status of the companies included in the sample. The percentage of companies having positive income before tax and R\&D is almost stable from 2004 to 2007 (82-84\%), while it decreases from 2008 onwards, declining to $72.7 \%$ in 2010 . The decrease in the number of profitable companies is basically due to the economic crisis.

Table 1 provides also information about the total value of R\&D expenditure over the period 2004-2010. The data show that sample companies increased continuously and strongly the value of investment in R\&D up to 2007, while the value settled in at the value of euro 4 million during the years 2007-2010.

Table 1. Profit status of companies and total value of $R \& D$ expenditure.

\begin{tabular}{lllll}
\hline \multirow{2}{*}{$\begin{array}{l}\text { Fiscal } \\
\text { Year }\end{array}$} & Observations & \multicolumn{2}{l}{$\begin{array}{l}\text { Income before taxes and } \\
\text { R\&D expenditure }\end{array}$} & $\begin{array}{l}\text { Total R\&D } \\
\text { expenditure }\end{array}$ \\
\cline { 3 - 4 } & & $\begin{array}{l}\text { Null or } \\
\text { negative }\end{array}$ & \\
\hline 2004 & 159 & 134 & 25 & 1,059 \\
2005 & 162 & 135 & 27 & 3,483 \\
2006 & 162 & 133 & 29 & 3,859 \\
2007 & 162 & 133 & 29 & 4,366 \\
2008 & 161 & 112 & 49 & 4,263 \\
2009 & 161 & 103 & 58 & 4,735 \\
2010 & 161 & 117 & 44 & 4,256 \\
\hline
\end{tabular}

Notes: The values of $\mathrm{R} \& \mathrm{D}$ expenditures are expressed in euro millions. Source: Authors' calculation on ORBIS data.

Summary statistics are reported in Table 2. The dummy variable for companies investing in $\mathrm{R} \& \mathrm{D}(R \& D C)$ shows that on average $17.2 \%$ of sample observations records a positive value of $R \& D$ expenditure. The empirical model uses two different proxies for R\&D intensity. The first $(R \& D I)$ is the ratio between $R \& D$ expenditure and total assets, and ranges between 0 and 0.362 (reaching a mean value of 0.006 ); the

10 A precise simulation of the marginal tax rate implies the knowledge of the value of losses of previous 4 years to carry-forward. Therefore, it has been necessary to impose sample companies to have balance sheet data available in every year between 1999 and 2010 .

11 I dropped observations having negative values of some variables, such as R\&D expenditure or sales. 
alternative proxy ( $\left.A L T \_R \& D I\right)$ is the ratio between $\mathrm{R} \& \mathrm{D}$ expenditure and total number of employees, and has a lower mean and a lower maximum value. By comparing fiscal variables, it emerges that $M T R$ has a mean value higher than
MTCR (respectively 0.262 and 0.107 ), implying that on average the fiscal benefit due to the deductibility of $R \& D$ expenditure is higher than the one due to $R \& D$ tax credit.

Table 2. Descriptive statistics for all variables, pooled for years 2004-2010 (obs.1,128).

\begin{tabular}{|c|c|c|c|c|c|}
\hline Definition & Variable & Mean & SD & Min & Max \\
\hline Dummy variable for companies with a positive $R \& D$ expenditure & $R \& D C$ & 0.172 & 0.378 & 0 & 1 \\
\hline R\&D intensity ( in \% of total assets) & $R \& D I$ & 0.006 & 0.021 & 0 & 0.362 \\
\hline R\&D intensity ( in \% of employees) & $A L T \_R \& D I$ & 0.001 & 0.004 & 0 & 0.032 \\
\hline Marginal tax credit rate & $M T C R$ & 0.158 & 0.166 & 0 & 0.382 \\
\hline Natural log of sales & $S$ & 5.749 & 1.905 & 0.367 & 11.591 \\
\hline Dummy variable for large companies & $L A R G E$ & 0.563 & 0.496 & 0 & 1 \\
\hline Market competition & $M C$ & 0.080 & 0.209 & 0.001 & 1 \\
\hline Natural log of number of employees & $E M P$ & 7.149 & 1.903 & 1.792 & 12.206 \\
\hline
\end{tabular}

\section{Estimation Results}

For the sake of comparison with prior literature, the empirical analysis starts by investigating the effect of nonfiscal variables on companies' R\&D choices.

The results of the probit analysis (Column 1.a of Table 3) show that, as expected, the bigger the company is, the higher is the probability to invest in $\mathrm{R} \& \mathrm{D}$. In line with previous literature [28], the log of company's sales results positively and significantly linked to companies' likelihood to invest in R\&D. On the contrary, $L A R G E$ results not statistically significant. $A G E$ is significantly and negatively linked to the probability to invest in $\mathrm{R} \& \mathrm{D}$, confirming that older companies have a lower propensity to invest in $R \& D$ than younger ones [28, 23]. Finally, market competition results not a significant factor affecting R\&D investment choice.

The tobit analysis (Column 1. b of Table 3) confirms that size and age of a company are significant factors affecting
R\&D expenditure: the bigger or the younger the company is, the higher the value of R\&D expenditure is. Contrary to the probit analysis, it emerges that market competition affects R\&D expenditure significantly and negatively. In line with the theoretical prediction [32], R\&D expenditure decreases in the presence of higher market competition: the higher competition lowers monopolistic profits of successful innovator, leading companies to reduce $R \& D$ expenditure.

When fiscal variables are added to the controls, it emerges a strong evidence of a fiscal effect influencing companies' R\&D decisions (columns 2 of Table 3 ). The positive and strongly significant coefficients associated to MTR show that the higher the tax saving due to R\&D deductibility, the more likely companies to invest in $R \& D$ and to increase $R \& D$ expenditure. Regression results imply that, due to $R \& D$ deductibility, a mean-level unit increase in the marginal tax rate raises the probability to invest in $R \& D$ by about $62 \%$ and $R \& D$ expenditure by about $21 \%$, respectively.

Table 3. Determinants of $R \& D$ investments.

\begin{tabular}{|c|c|c|c|c|c|c|c|c|}
\hline \multirow{2}{*}{\multicolumn{2}{|c|}{ Independent Variables }} & \multirow{2}{*}{ Expected Signs } & \multicolumn{2}{|l|}{1} & \multicolumn{2}{|l|}{2} & \multicolumn{2}{|l|}{3} \\
\hline & & & (a) & (b) & (a) & (b) & (a) & (b) \\
\hline \multirow{2}{*}{$\begin{array}{l}\text { Fiscal } \\
\text { variable }\end{array}$} & MTR & + & & & $\begin{array}{l}0.618 * * * \\
(0.133)\end{array}$ & $\begin{array}{l}0.211 * * * \\
(0.051)\end{array}$ & $\begin{array}{l}0.615 * * * \\
(0.131)\end{array}$ & $\begin{array}{l}0.221 * * * \\
(0.053)\end{array}$ \\
\hline & MTCR & N.S.S. & & & $\begin{array}{l}0.193 * * \\
(0.060)\end{array}$ & $\begin{array}{l}0.047 * * \\
(0.019)\end{array}$ & $\begin{array}{l}0.213 * * * \\
(0.058)\end{array}$ & $\begin{array}{l}0.056^{* *} \\
(0.019)\end{array}$ \\
\hline \multirow{2}{*}{ Other controls } & $\begin{array}{l}\text { S } \\
\text { LARGE }\end{array}$ & + & $\begin{array}{l}0.063 * * * \\
(0.008) \\
0.001 \\
(0.032)\end{array}$ & $\begin{array}{l}0.014 * * * \\
(0.003) \\
0.007 \\
(0.009)\end{array}$ & $\begin{array}{l}0.054 * * * \\
(0.008) \\
-0.007 \\
(0.031)\end{array}$ & $\begin{array}{l}0.012 * * * \\
(0.002) \\
0.004 \\
(0.009)\end{array}$ & $\begin{array}{l}0.055 * * * \\
(0.008) \\
0.003 \\
(0.029)\end{array}$ & $\begin{array}{l}0.012 * * * \\
(0.002) \\
0.009 \\
(0.009)\end{array}$ \\
\hline & $\begin{array}{l}\text { AGE } \\
\text { MC }\end{array}$ & $?$ & $\begin{array}{l}-0.020 * * \\
(0.009) \\
-0.018 \\
(0.047)\end{array}$ & $\begin{array}{l}-0.005 * \\
(0.003) \\
-0.033 * * \\
(0.012)\end{array}$ & $\begin{array}{l}-0.022 * * \\
(0.009) \\
-0.008 \\
(0.042)\end{array}$ & $\begin{array}{l}-0.005 * * \\
(0.003) \\
-0.028 * * \\
(0.011)\end{array}$ & $\begin{array}{l}-0.031 * * * \\
(0.009) \\
0.002 \\
(0.042)\end{array}$ & $\begin{array}{l}-0.008 * * \\
(0.003) \\
-0.017 \\
(0.012)\end{array}$ \\
\hline \multicolumn{2}{|c|}{ Regional dummies } & & No & & No & & Yes & \\
\hline \multicolumn{2}{|c|}{ Industry dummies } & & No & & No & & Yes & \\
\hline
\end{tabular}

Notes: column (a) provides the marginal effects (calculated at the means of the independent variables) of the impact of fiscal and non-fiscal factors on the probability to invest in R\&D; column (b) provides the estimates of the impact of control variables on R\&D expenditure. Robust standard errors in parentheses. Regressions in columns (a) use as dependent variable R\&DC, a dummy variable showing companies investing in R\&D activity; regression in columns (b) use as dependent variable R\&DI, the ratio between R\&D expenditure and total assets. MTR is the marginal tax rate computed using the Graham-Shevlin methodology; MTCR is the marginal tax credit deriving from R\&D investment; $\mathrm{S}$ is the log of sales; LARGE is a dummy variables showing companies having an added value above its median value; AGE is the log of the number of year since firm's foundation; MC is the ratio between firm's and industry's sales. Superscript asterisks indicate statistical significance at $0.01(* * *), 0.05(* *)$ and $0.10(*)$. 
Also MTCR affects positively and significantly both the probability to invest in $R \& D$ and $R \& D$ expenditure. This finding confirms the expectations that an increase in the tax credit due to $R \& D$ investment has positive effects on companies' R\&D choices. Comparing the coefficients estimated for both the fiscal variables, it emerges that R\&D behavior responds stronger to an increase in $M T R$ than in MTCR: a mean-level unit increase in the marginal tax credit rate raises the probability to invest in R\&D by about $19 \%$ and $R \& D$ expenditure by about $5 \%$, respectively.

The inclusion of the fiscal variables changes neither the sign nor the significance level of non-fiscal control variables.

The inclusion of regional and industrial dummies does not significantly affect the relationship between control variables and companies' R\&D choices. The results in Columns 3 are very similar to those estimated for the main model in terms of magnitude, sign and significance level. For expositional convenience, Table 3 reports the estimated coefficients neither for regional nor for industry dummies. However, it should be pointed out that regional dummies are not statistically linked to either the probability to invest in R\&D and R\&D expenditure, showing that the presence of different regional $R \& D$ incentives does not affect business $R \& D$ choices.

Table 4 reports the results of several sensitivity and robustness checks. First, to proxy for the fiscal saving due to R\&D deductibility, in alternative to the marginal tax rate, the taxable income dummy (TID) has been used. The taxable income dummy is a dichotomous variable based on the sign of current-period taxable income before $R \& D$ deductions [20]: TID takes a value equal to the top statutory tax rate for firms having positive income before taxes and before R\&D expenditure, and zero otherwise. The estimation results (Columns 1 of Table 4) confirm that an increase in fiscal benefit due to R\&D deductibility affects positively both the decision of companies to invest in $R \& D$ and $R \& D$ expenditure, even if the effect of $T I D$ on $\mathrm{R} \& \mathrm{D}$ choices is almost half of those estimated for MTR (Columns 3 of Table $3)$.

Table 4. Robustness.

\begin{tabular}{|c|c|c|c|c|c|c|c|c|}
\hline \multirow{2}{*}{\multicolumn{2}{|c|}{ Independent Variables }} & \multirow{2}{*}{ Expected Signs } & \multicolumn{2}{|l|}{1} & \multicolumn{2}{|l|}{2} & \multicolumn{2}{|l|}{3} \\
\hline & & & (a) & (b) & (a) & (b) & (a) & (b) \\
\hline \multirow{3}{*}{ Fiscal variable } & MTR & + & & & $\begin{array}{l}0.394 * * \\
(0.139)\end{array}$ & $\begin{array}{l}0.128 * * \\
(0.041)\end{array}$ & $\begin{array}{l}0.514 * * \\
(0.160)\end{array}$ & $\begin{array}{l}0.030 * * \\
(0.009)\end{array}$ \\
\hline & TID & + & $\begin{array}{l}0.370 * * * \\
(0.094)\end{array}$ & $\begin{array}{l}0.133 * * * \\
(0.037)\end{array}$ & & & & \\
\hline & MTCR & N.S.S. & $\begin{array}{l}0.209 * * * \\
(0.059)\end{array}$ & $\begin{array}{l}0.053 * * \\
(0.019)\end{array}$ & $\begin{array}{l}0.247 * * * \\
(0.066)\end{array}$ & $\begin{array}{l}0.060 * * \\
(0.020)\end{array}$ & $\begin{array}{l}0.222 * * \\
(0.078)\end{array}$ & $\begin{array}{l}0.009 * * \\
(0.004)\end{array}$ \\
\hline \multirow{5}{*}{ Other controls } & $\mathrm{S}$ & + & $\begin{array}{l}0.058 * * * \\
(0.008)\end{array}$ & $\begin{array}{l}0.013 * * * \\
(0.003)\end{array}$ & $\begin{array}{l}-0.042^{* *} \\
(0.017)\end{array}$ & $\begin{array}{l}-0.020^{* * *} \\
(0.006)\end{array}$ & $\begin{array}{l}0.077 * * * \\
(0.010)\end{array}$ & $\begin{array}{l}0.003 * * * \\
(0.001)\end{array}$ \\
\hline & LARGE & + & $\begin{array}{l}-0.002 \\
(0.030)\end{array}$ & $\begin{array}{l}0.008 \\
(0.009)\end{array}$ & $\begin{array}{l}-0.036 \\
(0.036)\end{array}$ & $\begin{array}{l}0.003 \\
(0.010)\end{array}$ & $\begin{array}{l}0.016 \\
(0.039)\end{array}$ & $\begin{array}{l}0.001 \\
(0.002)\end{array}$ \\
\hline & AGE & - & $\begin{array}{l}-0.028 * * \\
(0.009)\end{array}$ & $\begin{array}{l}-0.007 * * \\
(0.003)\end{array}$ & $\begin{array}{l}-0.039 * * * \\
(0.011)\end{array}$ & $\begin{array}{l}-0.010 * * \\
(0.003)\end{array}$ & $\begin{array}{l}-0.036^{* *} \\
(0.012)\end{array}$ & $\begin{array}{l}-0.002 * * \\
(0.001)\end{array}$ \\
\hline & $\mathrm{MC}$ & $?$ & $\begin{array}{l}0.001 \\
(0.044)\end{array}$ & $\begin{array}{l}-0.018 \\
(0.012)\end{array}$ & $\begin{array}{l}0.044 \\
(0.048)\end{array}$ & $\begin{array}{l}-0.007 \\
(0.011)\end{array}$ & $\begin{array}{l}0.005 \\
(0.055)\end{array}$ & $\begin{array}{l}-0.003 \\
(0.003)\end{array}$ \\
\hline & EMP & + & & & $\begin{array}{l}0.131 * * * \\
(0.018)\end{array}$ & $\begin{array}{l}0.039 * * * \\
(0.007)\end{array}$ & & \\
\hline \multicolumn{2}{|c|}{ Regional dummies } & & Yes & & Yes & & Yes & \\
\hline \multicolumn{2}{|c|}{ Industry dummies } & & Yes & & Yes & & Yes & \\
\hline \multicolumn{2}{|c|}{ Observations } & & 1,128 & & 794 & & 794 & \\
\hline
\end{tabular}

Notes: column (a) provides the marginal effects (calculated at the means of the independent variables) of the impact of fiscal and non-fiscal factors on the probability to invest in R\&D; column (b) provides the estimates of the impact of control variables on R\&D expenditure. Robust standard errors in parentheses. Regressions in columns (a) use as dependent variable R\&DC, a dummy variable showing companies investing in R\&D; regressions in columns (b) use as dependent variable R\&DI, the ratio R\&D expenditure to total assets. MTR is the marginal tax rate computed using the Graham-Shevlin methodology; MTCR is the marginal tax credit deriving from $R \& D$ investment; $S$ is the log of sales; LARGE is a dummy variables showing companies having an added value above its median value; AGE is the log of the number of year since firm's foundation; MC is the ratio between firm's and industry's sales; EMP is the log of total number of employees. In columns (1) I use an alternative proxy for marginal tax rate, TID, equal to the top statutory tax rate if a company has a positive income before taxes and R\&D expenditure; in columns (2) I add to controls the log of the number of employees; in columns 3 I use as dependent variable ALT_R\&DI, the ratio between R\&D expenditure and total number of employees.

Robust standard errors in parentheses. Superscript asterisks indicate statistical significance at $0.01(* * *), 0.05(* *)$ and $0.10(*)$.

In line with previous literature, the log of the number of employees is added to the control variables as measure of companies' size. The unavailability of such information for several companies over many years, implies a reduction in the number of observations. The estimation results (Columns 2 of Table 4) confirm the findings reached by previous literature, showing that an increase in the number of employees has a positive impact on R\&D choices. However, the inclusion of the number of employees among the controls reduces significantly the magnitude of the positive effect of $M T R$ on both the decision to invest in $\mathrm{R} \& \mathrm{D}$ and $\mathrm{R} \& \mathrm{D}$ magnitude, and increases the magnitude of the positive effect of MTCR.

Finally, the main analysis has been replicated by using an 
alternative proxy for $R \& D$ intensity, computed as the ratio between R\&D expenditure and total number of employees. The estimation results (Columns 3 of Table 4) are very similar to those obtained when estimating the main model (Columns 3 of Table 3). However, it emerges that an increase in both MTR and MTCR has a lower effect on R\&D expenditure (the coefficients decrease from $22.1 \%$ to $3 \%$ and from $5.6 \%$ to $0.9 \%$, respectively).

\section{Conclusions}

This paper investigates whether fiscal incentives affect companies' R\&D choices, focusing the analysis on the effect of marginal tax saving due to R\&D deductibility and to R\&D tax credits. The results deliver strong evidence that fiscal variables affect companies' decision to invest in $R \& D$, such as $R \& D$ expenditure.

The positive and strongly significant coefficients associated with MTR show that the higher the tax saving due to $\mathrm{R} \& \mathrm{D}$ deductibility is, the more likely companies are to invest in $\mathrm{R} \& \mathrm{D}$ and to increase $\mathrm{R} \& \mathrm{D}$ expenditure. $M T C R$ positively and significantly affects both the probability to invest in $R \& D$ and $R \& D$ expenditure, too. These findings confirm that $R \& D$ deductibility and $R \& D$ tax credits are instruments able to affect companies' R\&D choices, increasing companies' likelihood to invest in R\&D, and, fostering companies' R\&D expenditure.

The main limit of this study is that the empirical analysis is based on a sample composed of a few firms, which is not fully representative of the overall population of Italian companies. However, it would be interesting to replicate this analysis using different data and verifying whether it is possible to find convincing evidence on the robustness of the main results.

\section{Disclaimer}

The views expressed in this paper are those of the author and do not necessarily reflect the opinion of SOSE SpA.

\section{Acknowledgements}

This paper is part of the research project " $R \& D$ activity and HRM: an empirical investigation of the Italian case", Department of Economics, University of Salento (No. 2013: 5 per mille per la ricerca).

\section{References}

[1] Romer, P. M. (1990). Endogenous Technological Change. Journal of Political Economy 98(5), S71-S102.

[2] Grossman, G. M. and E. Helpman (1991). "Innovation and Growth in the Global Economy". Cambridge, MA: MIT Press.

[3] Arrow, K. J. "Economic welfare and the allocation of resources for invention", in The Rate and Direction of
Inventive Activity, R. R. Nelson, Eds. New York: Princeton Univ. Press, 1962.

[4] Berger, P. G. (1993). Explicit and implicit tax effects of the R\&D tax credit. Journal of Accounting Research 31(2), 131171.

[5] Hall, B. H. (2002). The financing of research and development. Oxford Review of Economic Policy 18(1), 35-51.

[6] Griffith, R., D. Sandler and J. Van Reenen (1996). Tax Incentives for R\&D. Fiscal Studies 16(2), 21-44.

[7] OECD (2010). "R\&D tax incentives: rationale, design, evaluation". OECD publishing.

[8] OECD (2013). "Science, Technology and Industry Scoreboard 2013”. OECD publishing.

[9] Hu, Y., W. Ju and K. Gao (2019). The review impact of the tax policies and fiscal policies on R\&D at the firm level. International Journal of Economics, Finance and Management Sciences 7(1), 1-5.

[10] Binelli, C. and A. Maffioli (2007). A Micro - econometric Analysis of Public Support to Private R\&D in Argentina. International Review of Applied Economics 21(3), 339-359.

[11] Baghana, R. and P. Mohnen (2009). Effectiveness of R\&D tax incentives in small and large enterprises: analysis of firm data in Québec. Small Business Economics 33(1), 91-107.

[12] Hall, B. H. and J. Van Reenen (2000). How effective are fiscal incentives for R\&D? A review of the evidence. Research Policy 29, 449-469.

[13] Mairesse, J. and P. Mohnen (2010). Using Innovation Surveys for Econometric Analysis. Handbook of the Economics of Innovation 2, 1129-1155.

[14] Hall, B. H. (1993). R\&D tax policy during the eighties: success or failure? Tax Policy and the Economy 7, 1-36.

[15] Hall, B. H., F. Lotti and J. Mairesse (2009). Innovation and productivity in SMEs: Empirical evidence for Italy. Small Business Economics 33, 13-33.

[16] Cerulli, G. and B. Potì (2012). Evaluating the robustness of the effect of public subsidies on firms' R\&D: An application to Italy. Journal of Applied Economics 15(2), 287-320.

[17] Bronzini, R. and P. Paolo (2016). The impact of R\&D subsidies on firm innovation. Research Policy 45(2), 442-457.

[18] Arachi, G. and V. Bucci (2019). The role of taxes in earnings management: evidence from writedowns of long-term equity investments. Finanzarchiv, forthcoming.

[19] Graham, J. R. (1996). Debt and the marginal tax rate. Journal of Financial Economics, 41(1), 41-73.

[20] Graham, J. R. (1996). Proxies for the corporate marginal tax rate. Journal of Financial Economics 42(2), 187-221.

[21] Graham, J. R. (1999). Do personal taxes affect corporate financing decisions? Journal of Public Economics, 73(2), 147185 .

[22] Shevlin, T. (1990). Estimating corporate marginal tax rates with asymmetric tax treatment of gains and losses. The Journal of the American Taxation Association 11(2), 51-67. 
[23] Almus, M. and D. Czarnitzki (2003). The Effects of Public R\&D Subsidies on Firm's Innovation Activities: The Case of Eastern Germany. Journal of Business and Economic Statistics 21 (2), 226-236.

[24] Tobin, J. (1958). Estimation of the relationship for limited dependent variables. Econometrica 26(1), 24-36.

[25] Maddala, G. S. (1987). Limited dependent variables using panel data. The Journal of Human Resources 22 (3), 307-338.

[26] Schumpeter, J. (1942). "Capitalism, socialism and democracy”. New York: Harper and Row.

[27] Galbraith, J. K. (1952). "American Capitalism, the Concept of Countervailing Power”. Boston: Houghton Mifflin Company.

[28] Clausen, T. H. (2009). Do subsidies have positive impacts on R\&D and innovation activities at the firm level? Structural Change and Economic Dynamics 20(4), 239-253.

[29] Bronzini, R. and E. Iachini (2011). Are Incentives for R\&D Effective? Evidence from a Regression Discontinuity Approach. Banca d'Italia Working paper no. 791.

[30] Busom, I (2000). An Empirical Evaluation of the Effects of R\&D Subsidies. Economics of Innovation and New Technology 9(2), 111-148.
[31] Hussinger, K. (2008). R\&D and subsidies at the firm level: An application of parametric and semiparametric two-step selection models. Journal of Applied Econometrics 23(6), 729-747.

[32] Aghion, P. and P. Howitt, Endogenous Growth Theory. Cambridge, MA: MIT Press, 1998.

[33] Blundell, R., R. Griffith and J. van Reenen (1999). Market Share, Market Value and Innovation in a Panel of British Manufacturing Firms. Review of Economic Studies 66(3), 529-554

[34] González, X., J. Jaumandreu and C. Pazó (2005). Barriers to Innovation and Subsidy Effectiveness. Rand Journal of Economics 36(4), 930-950.

[35] Takalo, T., T. Tanayama and O. Toivanen (2013). Estimating the benefits of targeted R\&D subsidies. The Review of Economics and Statistics 95(1), 255-272.

[36] Wallsten, S. (2000). The effects of government - industry R\&D programs on private $R \& D$ : the case of the SBIR Program. RAND Journal of Economics 31(1), 82-100.

[37] Blanes, J. W. and I. Busom (2004). Who participates in R\&D subsidy programs? The case of Spanish manufacturing firms. Research Policy 33(10), 1459-1476. 